\title{
Tracheal Perforation by an Oesophageal Stent
}

\author{
Tracheaperforation durch einen Ösophagusstent
}

Authors

Institutions
H. Knoop ${ }^{1}$, U. Knoop ${ }^{2}$, H.-C.-D. Martini ${ }^{3}$, L. Heining' ${ }^{1}$, R. Wolf' ${ }^{1}$, S. Ewig' ${ }^{1}$, E. Hecker ${ }^{4}$

Institutions are listed at the end of article. received 20.8.2012

accepted 23.8.2012

\section{Bibliography}

DOI http://dx.doi.org/

$10.1055 / \mathrm{s}-0032-1325684$

Pneumologie 2012; 66: 607-609

(c) Georg Thieme Verlag KG

Stuttgart · New York

ISSN 0934-8387

\section{Corresponding author \\ Dr. med. Heiko Knoop}

Thoraxzentrum Ruhrgebiet

Klinik für Pneumologie und Infektiologie

Evangelisches Krankenhaus

Herne - Betriebsstelle Eickel

Akademisches Lehrkrankenhaus der Universität Duisburg-Essen

Hordeler Str. 7-9

44651 Herne

Heiko.Knoop@web.de

\section{Abstract \\ $\nabla$}

In a 63 year-old female patient with oesophageal carcinoma a tracheal perforation by an oesophageal stent was diagnosed. A first attempt of tracheal stenting was not successful due to spontaneous dislocation of the stent. Therefore, a shorter stent was chosen and correctly placed in a second session. This case report on an oesophagotracheal fistula provides a summary of this complication in advanced oesophageal cancer.

\section{Case report}

$\nabla$

A 63 year-old female patient was transferred to our hospital for further evaluation of an unusual tracheal lesion. In November 2011, an advanced ulcerating low differentiated keratinizing squamous cell carcinoma (SCC) of the oesophagus had been diagnosed. Palliative chemotherapy and radiotherapy had been performed in the past but had to be stopped later on due to progressive disease and deterioration in ECOG (Eastern Cooperative Oncology Group) Performance Status [1]. In February 2012, endoscopic dilation and implantation of an oesophageal stent was necessary due to stenosis. Since the beginning of July 2012, the patient suffered from hoarseness and progressive cough without expectoration and therefore was admitted to the hospital where the oesophageal carcinoma (EC) was first diagnosed and treated. Computed tomography ( $\mathbf{F i g . 1} \mathbf{a}-\mathbf{c}$ ) and bronchoscopy were performed before transfer to our hospital.

On first inspection with flexible bronchoscopy a long segmental penetration of the oesophageal stent into the trachea was obvious, covering the complete tracheal width and a length of $3.6 \mathrm{~cm}$ ( $\bullet$ Fig. 2). The distance to the main carina was

\section{Zusammenfassung \\ $\nabla$}

Bei einer 63-jährigen Patientin mit Ösophaguskarzinom wurde eine Tracheaperforation durch einen Ösophagusstent diagnostiziert. Ein erster Versuch der Versorgung mit einem Trachealstent erwies sich aufgrund einer spontanen Dislokation des Stents als nicht erfolgreich. Aus diesem Grund wurde im Rahmen einer erneuten starren Bronchoskopie ein kürzerer Stent platziert mit anhaltend korrekter Lage. Dieser Fallbericht über eine ösophagotracheale Fistel gibt eine kurze Übersicht über diese Komplikation bei Patienten mit fortgeschrittenem Ösophaguskarzinom.

$3 \mathrm{~cm}$ and to the vocal cord-planar approximately $4 \mathrm{~cm}$. The penetration caused a slot-shaped high grade stenosis of the trachea which could be passed easily with the bronchoscope. Additionally, the mucosa of the middle lobe was swollen with consecutive concentric constriction of the middle lobe ostium. Histological analysis of the mucosal biopsy revealed SCC with adenocarcinoma components according to a pulmonary metastasis of the EC. Implantation of a tracheal stent $(80 \mathrm{~mm} \times 20 \mathrm{~mm})$ via rigid bronchoscopy was performed and seemed to be successful with correct bronchoscopic localization of the stent. However, the patient developed severe hypoxemia shortly after the procedure. X-ray suggested a dislocation of the stent ( $\bullet$ Fig. 3 a) which had to be retracted immediately. In a second session a covered expandable nitinol stent $(60 \times 20 \mathrm{~mm}$, nickel-titanium alloy, Micro-Tech Europe) was implanted successfully ( Fig.3b) with a distance to both main carina and vocal cord planar of $1 \mathrm{~cm}$, respectively ( Fig.4a,b). Flexible bronchoscopy confirmed the correct localization of the stent one day after implantation. The patient could be retransferred for further palliative treatment. 


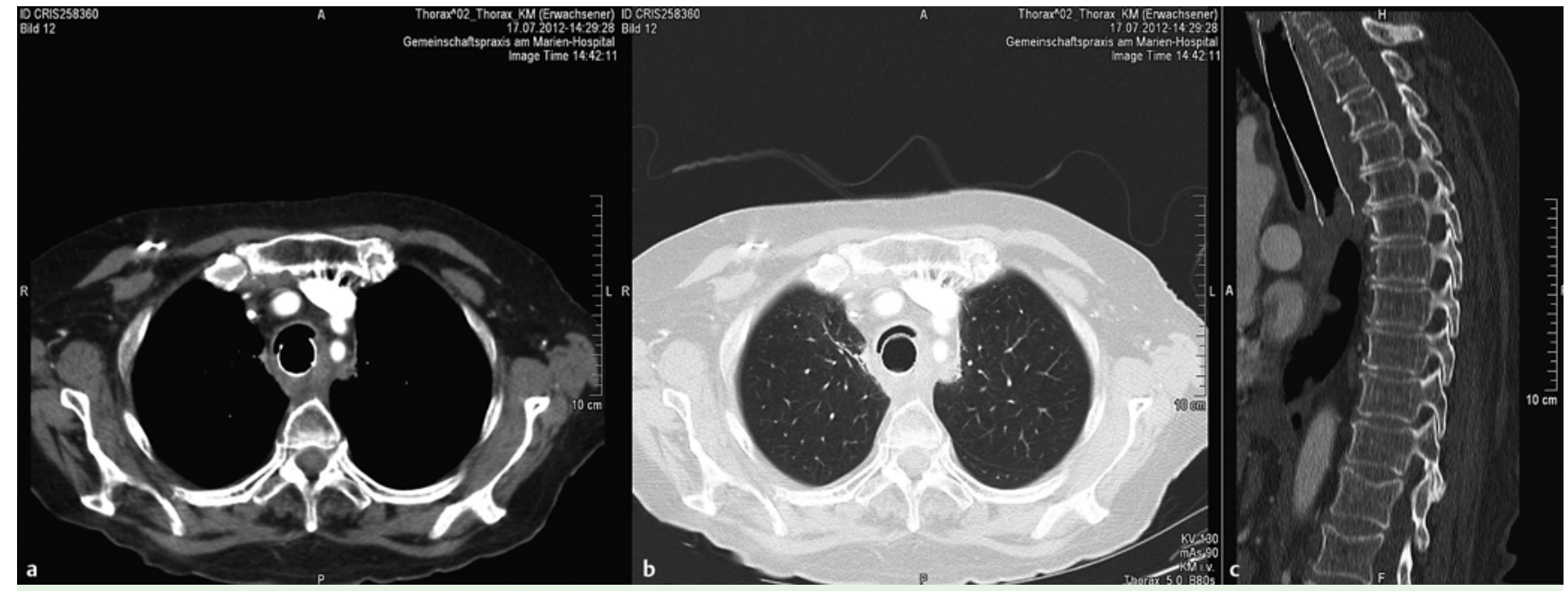

Fig. 1 Oesophago-tracheal fistula of $3.6 \mathrm{~cm}$ length after oesophageal stenting with high grade tracheal stenosis.

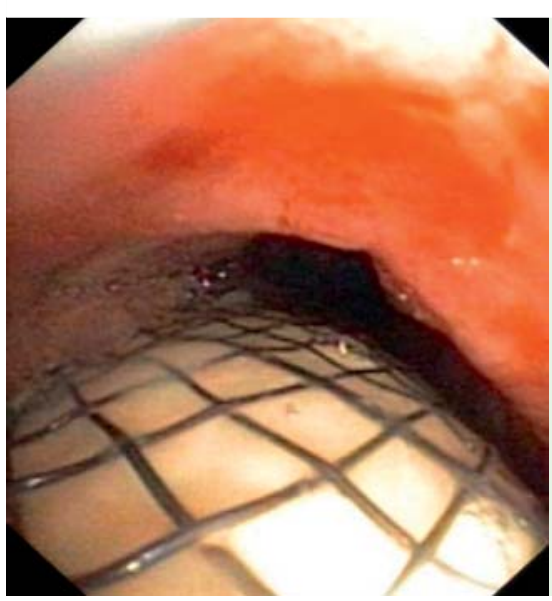

Fig. 2 Oesophageal stent penetrating the trachea through the dorsal tracheal wall and causing high grade stenosis in bronchoscopy.

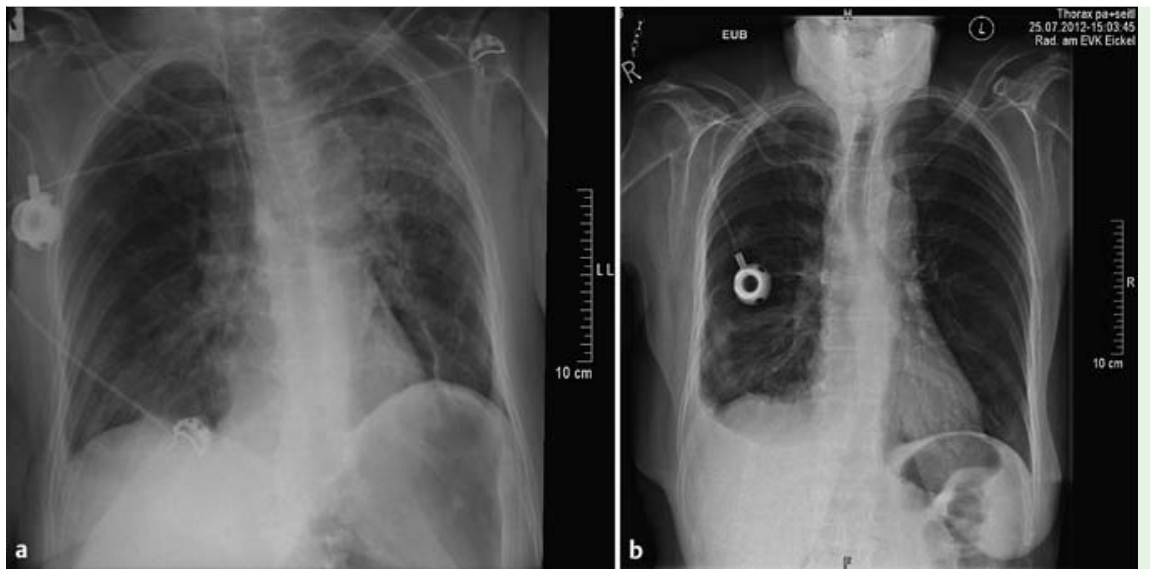

Fig. 3 a Infiltrative lesion in the left upper pulmonary lobe highly suggestive for dislocation of the tracheal stent, $\mathbf{b}$ Correct localization of the oesophageal stent in X-ray. Due to reduced performance status, a standing lateral radiograph to visualize the correct position of the tracheal stent was not possible.

\section{Discussion}

$\nabla$

EC is the sixth most common cause among cancer related deaths [2]. Risk factors for EC identified so far include alcohol abuse [3], chewing tobacco [2] and low consumption of fruit and vegetable [4]. Diagnosis, treatment and follow-up should be performed according to current guidelines [5,6]. Advanced EC may erode into adjacent structures and hereby cause esophagorespiratory fistulas (ERF). This complication with relevant impact on prognosis occurs in less than $20 \%$ of patients with EC [7]. The main fistula site is the trachea [8]. Several fistulas may occur in the same patient [9]. Computertomography and bronchoscopy are the main diagnostic tools for further evaluation. In patients with EC and good performance status, surgery remains a treatment option for ERF. Besides surgical treatment, stenting of oesophagus, airway or both is an efficient palliative therapeutic alternative which can relieve symptoms and may improve survival [10,11]. Symptoms can be mainly attributed to pulmonary infections due to recurrent aspiration. 

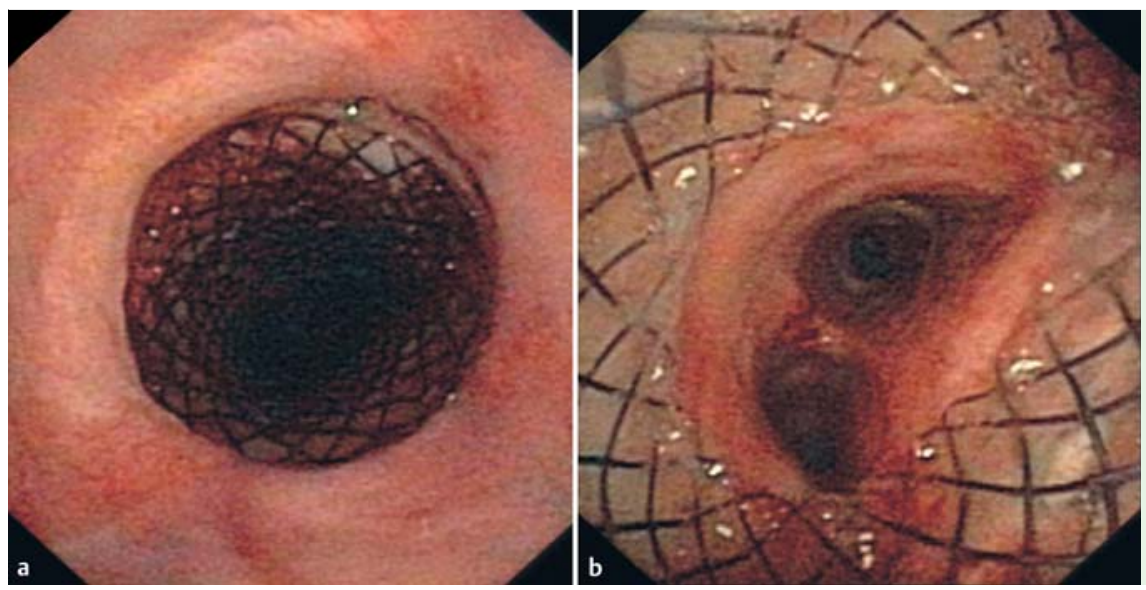

Fig.4 Tracheal stent with a distance to both main carina and vocal cord planar of $1 \mathrm{~cm}$, respectively, in bronchoscopy.

Tracheal perforation has been a common complication in 15 to $40 \%$ of patients after oesophageal stenting with conventional unexpandable plastic prostheses which was the treatment of choice for ERF until the early 1990s [12]. Nowadays, the use of covered expandable metallic stents has been established as these stents show less procedural complications [13]. However, perforation of the trachea by this type of oesophageal stents has also been described [14].

\section{Acknowledgements}

The authors thank the "Radiologie Herne" (Dr. med. T. Magin) for the permission to use the X-rays.

\section{Conflict of interest}

$\nabla$

The authors have no conflict of interest.

\section{Institutions}

${ }^{1}$ Thoraxzentrum Ruhrgebiet, Klinik für Pneumologie und Infektiologie, EVK Herne - Betriebsstelle Eickel (Prof. Dr. med. S. Ewig)

2 Berufsgenossenschaftliches Universitätsklinikum Bergmannsheil, Medizinische Klinik III - Pneumologie, Allergologie, Schlaf- und Beatmungsmedizin (Prof. Dr. med. J. Behr)

3 Radiologie Witten (Dr. med. H.-C.-D. Martini)

${ }^{4}$ Thoraxzentrum Ruhrgebiet, Klinik für Thoraxchirurgie, EVK Herne Betriebsstelle Eickel (Dr. med. Dipl.-Oec. E. Hecker)

\section{References}

1 Oken MM, Creech RH, Tormey DC et al. Toxicity and responsive criteria of the Eastern Cooperative Oncology Group. Am J Clin Oncol 1982; 5: 649-655

2 Agrawal N, Jiao Y, Bettegowda C et al. Comparative genomic analysis of esophageal adenocarcinoma and squamous cell carcinoma. Cancer Discov 2012: epub ahead of print

3 WHO. Global health risks: mortality and burden of disease attributable to selected major risks. Geneva: World Health Organization; 2009; 21 : Available from: http://www.who.int/healthinfo/global_burden_disease/GlobalHealthRisks_report_full.pdf

4 Lock K, Pomerleau J, Causer L et al. Low fruit and vegetable consumption. In: Ezzati M, Lopez AD, Rodgers A, Murray CJL eds. Comparative quantification of health risks: global and regional burden of disease attributable to selected major risk factors. Geneva: World Health Organization; 2004: $597-728$

5 Stahl M, Budach W, Meyer H-J et al. Esophageal cancer: Clinical Practice Guidelines for diagnosis, treatment and follow-up. Ann Oncol 2010; 21 (Suppl. 5): v46-v49

6 Moehler M, Al-Batran SE, Andus T et al. [German S3-guideline "Diagnosis and treatment of esophagogastric cancer"]. Z Gastroenterol 2011; 49: $461-531$

7 Martini N, Goodner JT, D'Angio GJ et al. Tracheooesophageal fistula due to cancer. J Thorac Cardiovasc Surg 1970; 59: 319-324

8 Duranceau A, Jamieson GG. Malignant tracheoesophageal fistula. Ann Thorac Surg 1984; 37: 346-354

9 Hamai Y, Hihara J, Emi M et al. Successful management of multiple esophagorespiratory fistulas using two types of stent: report of a case. Surg Today 2011; 41: 560-562

10 Chung FT, Lin HC, Chou CL et al. Airway ultraflex stenting in esophageal cancer with esophagorespiratory fistula. Am J Med Sci 2012; 344: $105-109$

11 Hamai $Y$, Hihara J, Emi $M$ et al. Airway stenting for malignant respiratory complications in esophageal cancer. Anticancer Res 2012; 31 : $1785-1790$

12 Weigert $N$, Neuhaus $H$, Rosch $T$ et al. Treatment of esophagorespiratory fistulas with silicone-coated self-expanding metal stents. Gastrointest Endosc 1995; 41: $490-496$

13 Shin JH, Song HY, Ko GY et al. Esophagorespiratory fistula: long-term results of palliative treatment with covered expandable metallic stents in 61 patients. Radiology 2004; 232: 252-259

14 Katsanos K, Sabharwal T, Koletsis $E$ et al. Direct erosion and prolapse of esophageal stents into the tracheobronchial tree leading to life-threatening airway compromise. J Vasc Interv Radiol 2009; 20: 1491 - 1495 